\title{
RESEARCH ON EVALUATION OF PPP PROJECT CONSTRUCTION QUALITY MANAGEMENT EFFECT BASED ON MATTER-ELEMENT MODEL
}

\author{
Ping $\mathrm{Hu}^{1}$, Bo Liu ${ }^{2}$, Kewei $\mathrm{Tan}^{3}$, Yun $\mathrm{Li}^{4}$ and Xiaojun Zhang ${ }^{5}$ \\ ${ }^{1}$ Postgraduate, Ginling College, Nanjing Normal University, Nanjing \\ ${ }^{2}$ Associate Professor, Ginling College, Nanjing Normal University, Nanjing \\ ${ }^{3}$ Lecture, Chengxian College, Southeast University, Nanjing \\ ${ }^{4}$ Associate Professor, Ginling College, Nanjing Normal University, Nanjing \\ ${ }^{5}$ Lecture, Ginling College, Nanjing Normal University, Nanjing
}

DOI: 10.46609/IJSSER.2021.v06i02.005 URL: https://doi.org/10.46609/IJSSER.2021.v06i02.005

\begin{abstract}
As an important part of project implementation management, project construction quality management directly affects the realization of other project targets. The project company should strengthen the management of PPP project construction quality. This paper constructs an evaluation index system of PPP project construction quality management effect from four aspects- economic benefits, quality management methods, quality management satisfaction of other participants, innovation and improvement of quality management methods, and builds an evaluation model based on matter-element model. The research results provide effective support for the development of PPP project construction quality management.
\end{abstract}

Keywords: :PPP project construction quality; Evaluation of quality management effect; Matterelement model

\section{Introduction}

It is currently a widely used method in all countries in the world by using PPP mode for infrastructure project construction and operation. As the implementing organization of PPP project, the project company undertakes a series of work such as project financing, project implementation management and project operation management, which is the main organization of PPP project operation. Among them, project construction quality management is an important part of project implementation management, and its management effect directly affects the 


\section{International Journal of Social Science and Economic Research}

ISSN: $2455-8834$

Volume:06, Issue:02 "February 2021"

realization of other project targets. The project company should strengthen the management of PPP project construction quality.

In the process of PPP project implementation, the project implementation organization is faced with many uncertain factors. In order to ensure the construction quality of the project, it is necessary to equationte specific implementation measures in combination with the quality assurance system of the project during the implementation of the project, and to give timely feedback on the implementation effect of the quality management system. Through regular and irregular evaluation, the possible problems and deficiencies in the quality management system are found, and then corresponding measures are taken to make up for them in time to ensure the effectiveness of the project construction quality management system.

\section{Construction Quality and Effect Evaluation Index System of PPP Project}

\subsection{Construction of Level-1 index system for PPP project construction quality effect evaluation}

In the process of PPP project implementation, the effectiveness of project construction quality management is related to many factors, which can be divided into four categories-Economic benefits brought by project construction quality management, attitudes of other participants towards the effectiveness of the project construction quality management of the implementer, advantages and disadvantages of the project construction quality management methods of the implementing party, and enthusiasm of the implementers for the innovation and improvement of the project construction quality management methods. Among them, the economic benefits brought by the project construction quality management refer to the economic conversion of the costs paid due to the improvement of the project construction quality management effect and the economic conversion of the benefits brought by the improvement of the quality management effect during the implementation of PPP projects. The attitude of other participants towards the quality management effect of the project implementer mainly refers to the feedback of other project participants, such as the project owner, the project management unit, the project designer and the government department, on the construction quality management effect of the PPP project as the specific undertaker of the project construction during the implementation of the PPP project. The quality of the project construction quality management methods of the implementer refers to the quality management methods adopted by the project implementer during the PPP project implementation process and the project implementation organization during the project implementation process. The enthusiasm for innovation and improvement of project construction quality management methods mainly refers to the effectiveness of innovative thinking on project construction quality management methods and measures by 
project implementation agencies in order to cope with environmental changes and various uncertainties and ensure project construction quality during the implementation of PPP projects.

In conclusion, the evaluation of PPP project construction quality management effect can be carried out from four aspects- economic benefits, quality management methods, quality management satisfaction of other participants, innovation and improvement of quality management methods, so as to ensure the comprehensiveness and accuracy of quality management effect evaluation.

\subsection{Construction of the Level-2 index system of the quality management effect evaluation index system}

The Level-1 index economic benefit $\left(\mathrm{X}_{1}\right)$ can be measured from the two dimensions of quality management expenditure $\left(\mathrm{U}_{11}\right)$ and quality management benefit $\left(\mathrm{U}_{12}\right)$.

The quality management satisfaction of other participants $\left(\mathrm{X}_{2}\right)$ in the Level-1 index can be measured from four dimensions: satisfaction of government quality supervision department $\left(U_{21}\right)$, satisfaction of owner $\left(U_{22}\right)$, satisfaction of supervisor $\left(U_{23}\right)$ and satisfaction of designer $\left(\mathrm{U}_{24}\right)$.

The Level-1 index quality management method $\left(\mathrm{X}_{3}\right)$ can be measured from four dimensions: quality plan preparation method $\left(\mathrm{U}_{31}\right)$, quality management implementation method $\left(\mathrm{U}_{32}\right)$, quality management inspection method $\left(\mathrm{U}_{33}\right)$ and quality management feedback method $\left(\mathrm{U}_{34}\right)$.

The Level-1 index innovation and improvement of the quality management method $\left(\mathrm{X}_{4}\right)$ can be measured from four dimensions: the innovation of quality plan preparation method $\left(\mathrm{U}_{41}\right)$, the innovation of quality management implementation method $\left(\mathrm{U}_{42}\right)$, the innovation of quality management inspection method $\left(\mathrm{U}_{43}\right)$ and the innovation of quality management feedback method $\left(\mathrm{U}_{44}\right)$.

\subsection{Final formation of quality management effect evaluation index system}

According to the above analysis, an index system for evaluating the construction quality management effect of PPP projects is constructed, as shown in Table 1.

\section{Table 1Evaluation Index System of PPP Project Construction Quality Management Effect}

\begin{tabular}{c|c|c}
\hline Target Layer & Level-1 Indexes & Level-2 Indexes \\
\hline $\begin{array}{c}\text { Evaluation of Construction } \\
\text { Quality Management Effect of }\end{array}$ & Economic benefit $\mathrm{X}_{1}$ & Quality Management \\
\hline
\end{tabular}


International Journal of Social Science and Economic Research

ISSN: 2455-8834

Volume:06, Issue:02 "February 2021"

\begin{tabular}{|c|c|c|}
\hline \multirow[t]{13}{*}{ PPP Project } & & $\begin{array}{l}\text { Quality Management Benefit } \\
\qquad \mathrm{U}_{12}\end{array}$ \\
\hline & \multirow{4}{*}{$\begin{array}{l}\text { Quality Management } \\
\text { Satisfaction of Other } \\
\text { Participants } \mathrm{X}_{2}\end{array}$} & $\begin{array}{c}\text { Satisfaction of Government } \\
\text { Quality Supervision Department } \\
\mathrm{U}_{21}\end{array}$ \\
\hline & & Satisfaction of Owner $U_{22}$ \\
\hline & & Satisfaction of Supervisor $\mathrm{U}_{23}$ \\
\hline & & Satisfaction of Designer $U_{24}$ \\
\hline & \multirow{4}{*}{$\begin{array}{l}\text { Quality Management Method } \\
\qquad \mathrm{X}_{3}\end{array}$} & $\begin{array}{c}\text { Quality Plan Preparation } \\
\text { Method } U_{31}\end{array}$ \\
\hline & & $\begin{array}{c}\text { Quality Management } \\
\text { Implementation Method } \mathrm{U}_{32}\end{array}$ \\
\hline & & $\begin{array}{l}\text { Quality Management Inspection } \\
\text { Method } \mathrm{U}_{33}\end{array}$ \\
\hline & & $\begin{array}{c}\text { Quality Management Feedback } \\
\text { Method } \mathrm{U}_{34}\end{array}$ \\
\hline & \multirow{4}{*}{$\begin{array}{l}\text { Innovation and Improvement of } \\
\text { Quality Management Methods } \\
\mathrm{X}_{4}\end{array}$} & $\begin{array}{l}\text { Innovation of Quality Plan } \\
\text { Preparation Method } \mathrm{U}_{41}\end{array}$ \\
\hline & & $\begin{array}{c}\text { Innovation of Quality } \\
\text { Management Implementation } \\
\text { Methods } \mathrm{U}_{42}\end{array}$ \\
\hline & & $\begin{array}{c}\text { Innovation of Quality } \\
\text { Management Inspection } \\
\text { Methods } \mathrm{U}_{43}\end{array}$ \\
\hline & & $\begin{array}{c}\text { Innovation of Quality } \\
\text { Management Feedback } \\
\text { Methods } \cup_{44}\end{array}$ \\
\hline
\end{tabular}

\section{Construction Quality Management Effect Evaluation Model of PPP Project}

Because there are many models that can be used for evaluation, and each model has its own characteristics and scope of application. On the basis of comparative analysis of the main comprehensive evaluation models, this paper uses matter-element model and group decisionmaking Analytic Hierarchy Process (AHP) to construct PPP project construction quality management effect evaluation model. 
The steps for establishing the PPP project construction quality management effect evaluation model based on matter-element model are as follows:

Step1: Determine classic domain and section domain

The construction quality management effect of PPP projects is divided into five levels, namely, very high, high, general, low and very low. Therefore, the evaluation indexes of PPP project construction quality management effect are divided into five levels from low to high: level-1, level-2, level-3, level-4 and level-5. Level-1 represents very low, level-2 represents relatively low, level-3 represents general, level-4 represents relatively high, and level-5 represents very high.

Under the Level-1 index of economic benefit ( $X_{1}$ ), the classical domain $R_{0 j}$ of each Level is

$$
\begin{aligned}
& R_{01}=\left[\begin{array}{ccc}
\text { Level }-1 & U_{11} & 0-20 \\
& U_{12} & 0-20
\end{array}\right], R_{02}=\left[\begin{array}{ccc}
\text { Level }-2 & U_{11} & 20-40 \\
& U_{12} & 20-40
\end{array}\right], \\
& R_{03}=\left[\begin{array}{cccc}
\text { Level }-3 & U_{11} & 40-60 \\
& U_{12} & 40-60
\end{array}\right], R_{04}=\left[\begin{array}{ccc}
\text { Level }-4 & U_{11} & 60-80 \\
& U_{12} & 60-80
\end{array}\right], R_{05}=\left[\begin{array}{ccc}
\text { Level }-5 & U_{11} & 80-100 \\
& U_{12} & 80-100
\end{array}\right]
\end{aligned}
$$

Node Domain $=[($ Economic Benefit $)]$, is $R_{p 1}=\left[\begin{array}{ll}U_{11} & 0-100 \\ U_{12} & 0-100\end{array}\right]$.

The classical domain and section domain of each level under other indexes are analogized.

Step2: Determine the evaluation index ${ }{ }_{i}$ and its weight $U_{i s}$

Thereare many methods to determine the weight of evaluation index system, such as expert scoring method, AHP, entropy method, etc. Each method has its own characteristics and limitations. The group AHP is selected to determine the index weight, and the weight distribution of the Level-1 evaluation index $X_{i}$ is set as $a_{i}(i=1,2, \ldots, 4)$, the Level-1 index weight vector $A=\left(a_{1}, a_{2} \ldots, a_{5}\right)$, and satisfies $a_{i} \geq 0$, and $\sum_{i=1}^{5} a_{i}=1$; Set the weight distribution of the Level-2 evaluation index $U_{i s}$ as $a_{i s}\left(i=1,2, \ldots, 4 ; s=1,2, \ldots, n_{i}\right)$. The weight vector of each Level-2 index is $A_{i}=\left(a_{i 1}, a_{i 2}, \ldots, a_{i n}\right)$ and satisfies $a_{i s} \geq 0, \sum_{s=1}^{n_{i}} a_{i s}=1$.

Step3: Determine the matter-element to be evaluated 


\section{International Journal of Social Science and Economic Research}

ISSN: 2455-8834

Volume:06, Issue:02 "February 2021"

The evaluation experts respectively rated the construction quality management effect of PPP projects according to the above index system and evaluation criteria, and took the average value of the scores assigned by each expert as the value $u_{i n}$ of the index. According to the listed index system, the number of matter-elements to be evaluated $m$ is 5 in the evaluation of PPP project construction quality management effect. Set the object to be evaluated be $P_{m} \quad(m=0,1, \ldots, 4)$, and the respective calculation results are expressed by matter-element $R_{m}$, which are called matter-elements to be evaluated. Then the matter-elements to be evaluated for comprehensive evaluation of PPP project construction quality management effect respectively are

$$
\begin{aligned}
& R_{1}=\left[\begin{array}{lll}
p_{1} & U_{11} & u_{11} \\
& U_{12} & u_{12}
\end{array}\right], \quad R_{2}=\left[\begin{array}{lll}
p_{2} & U_{21} & u_{21} \\
& U_{22} & u_{22} \\
& U_{23} & u_{23} \\
& U_{24} & u_{24}
\end{array}\right], R_{3}=\left[\begin{array}{lll}
p_{3} & U_{31} & u_{31} \\
& U_{32} & u_{32} \\
& U_{33} & u_{33} \\
& U_{34} & u_{34}
\end{array}\right], \\
& R_{4}=\left[\begin{array}{lll}
p_{4} & U_{41} & u_{41} \\
& U_{42} & u_{42} \\
& U_{43} & u_{43} \\
& U_{44} & u_{44}
\end{array}\right], R_{0}=\left[\begin{array}{ccc}
p_{0} & X_{1} & x_{1} \\
& X_{2} & x_{2} \\
& X_{3} & x_{3} \\
X_{4} & x_{4}
\end{array}\right]
\end{aligned}
$$

Among them,

$\mathrm{R}_{0}-$ Matter-element to Evaluate the Effect of PPP Project Construction Quality Management;

$\mathrm{R}_{1}$ — Matter-element for Evaluating Economic Benefits;

$\mathrm{R}_{2}$ _- Matter-element for Evaluation of Quality Management Methods;

$\mathrm{R}_{3}$ —Evaluation Matter-element of Quality Satisfaction of Other Participants;

$\mathrm{R}_{4}$ - Matter-element for Evaluation of Innovation and Improvement of Quality Management Methods;

$\mathrm{x}_{\mathrm{i}}(\mathrm{i}=1,2, \ldots, 4) \longrightarrow$ Weighted Value of the Criterion Level index.

Among them, for the two indexes of quality management expenditure $\left(U_{11}\right)$ and quality management benefit $\left(\mathrm{U}_{12}\right)$, quantitative evaluation is adopted in the specific evaluation, and the calculation equations are as follows:

Quality management expenditure $=100-\frac{(\text { Actual value of quality management expenditure }- \text { Target value of quality management expenditure })}{\text { Target value of quality management expenditure }} \times 100$ 
Quality management benefit $=\frac{\text { Actual benefit of quality management expenditure in a period }}{\text { Actual value of quality management expenditure in a period }} \times 100$

For the other 12 indexes, the value of the index is determined by expert evaluation.

Step4: Determine the correlation degree of each index of the matter-element to be evaluated with respect to each level $j$

Set

$$
K_{j}\left(x_{i}\right)=\left\{\begin{array}{l}
\frac{\rho\left(x_{i}, x_{0 j i}\right)}{\rho\left(x_{i}, x_{p i}\right)-\rho\left(x_{i}, x_{0 j i}\right)}, \text { 当 } \rho\left(x_{i}, x_{p i}\right)-\rho\left(x_{i}, x_{0 j i}\right) \neq 0 \text { 时 } \\
-\rho\left(x_{i}, x_{0 j i}\right)-1, \quad \text { 当 } \rho\left(x_{i}, x_{p i}\right)-\rho\left(x_{i}, x_{0 j i}\right)=0 \text { 时 }
\end{array}\right.
$$

Among them,

$$
\begin{gathered}
\rho\left(x_{i}, x_{0 j i}\right)=\left|x_{i}-\frac{1}{2}\left(a_{0 j i}+b_{0 j i}\right)\right|-\frac{1}{2}\left(b_{0 j i}-a_{0 j i}\right)(2) \\
\rho\left(x_{i}, x_{p i}\right)=\left|x_{i}-\frac{1}{2}\left(a_{p i}+b_{p i}\right)\right|-\frac{1}{2}\left(b_{p i}-a_{p i}\right)
\end{gathered}
$$

In the above equation, $\rho\left(x_{i}, x_{0 j i}\right)$ is the distance between a point $x_{i}$ and an interval $x_{0 j i}$, and $\rho\left(x_{i}, x_{p i}\right)$ is the distance between a point $x_{i}$ and an interval $x_{p i}$.

Step5: Calculate the correlation degree of the things $P_{m}$ to be evaluated with respect to each level $j$

If the weight coefficient of the index $X_{i}$ is $a_{i}$, and $\sum_{i=1}^{n} a_{i}=1$, then

$$
K_{j}(p)=\sum_{i=1}^{n} a_{i} K_{j}\left(x_{i}\right)
$$

In the equation, $K_{j}(p)$ is the combination value of the correlation degree of each index of the thing to be evaluated on each level under the consideration of the index weight. This equation is not only the correlation degree calculation model of each evaluation module about the level $j$, but also the correlation degree calculation model of the whole thing to be evaluated about the evaluation level $j$.

Step6: Rating 
If $K_{j_{0}}(p)=\max _{j \in(1,2, \ldots, m)} K_{j}(p), P_{m}$ is evaluated to belong to level $j_{0}$.

It can not only evaluate the effect of PPP project construction quality management as a whole, and analyze the quality management effect of the project implementing organization in PPP project implementation from a macro perspective, but also can evaluate the economic benefits of PPP project construction quality management effect, quality management methods, quality management satisfaction of other participants, innovation and improvement of quality management methods. Therefore, it is beneficial for the project implementation organization to have a more intuitive understanding of its quality management level, which finds out the deficiencies and facilitating the improvement of quality management.

\section{Case Analysis}

When carrying out the evaluation of the construction quality management effect of Huai'an Airport PPP project, the evaluation team independently collects and processes the data. During the whole process of the implementation of the project, four data evaluations were carried out and the data were processed. Through evaluation activities, comparison and analysis are carried out to find out the possible problems and deficiencies and ensure the smooth development of the PPP project construction quality management effect evaluation.

\subsection{Evaluation of construction quality management effect of Huai'an Airport PPP project based on matter-element-GAHP model}

When carrying out the evaluation of construction quality management effect of Huai'an Airport PPP project, firstly, the index weight is determined, and then the established data collection and evaluation are carried out four times in the process of project implementation, so as to reflect the changes of PPP project construction quality management effect in different periods and provide suggestions for the project construction quality management.

STEP1: Determine the Index Weight

When determining the weight of each index in the quality management effect evaluation index system, the experts of the evaluation team independently carry out the work. In particular, the members respectively determine the index weight suitable for the PPP project construction quality management effect evaluation index system according to the requirements and steps of the AHP. Then, the average value of the index weight determination results of each member is taken as the index weight of the PPP project construction quality management effect evaluation index system. 
International Journal of Social Science and Economic Research

ISSN: 2455-8834

Volume:06, Issue:02 "February 2021"

After calculation and analysis, the weight determination of each index in the PPP project construction quality management effect evaluation index system is shown in Table 2.

STEP2: Determine the Index Eigenvalues

When evaluating the effect of PPP project construction quality management, the members would judge the quality management effect of PPP projects according to the constructed evaluation index system of PPP project construction quality management effect. For quantitative indexes, the members would independently evaluate to ensure the effectiveness of quality management effect evaluation.

On the basis of the evaluation of each member of the evaluation team, the arithmetic average value of each member's evaluation value for each Level-2 index is taken as the index characteristic value of each Level-2 index. See Table 3 for the characteristic values of each Level-2 index in the PPP project construction quality management effect evaluation index system.

STEP3: Determine the correlation function value of each index of the matter-element to be evaluated with respect to each level $\mathrm{j}$

According to Equation (1)-Equation (3), calculate the correlation function values of each matterelement to be evaluated on each level, and see Table 4 for the calculation results.

Table 2 Weights of Level-2 Indexes in PPP Project Construction Quality Management of Effect Evaluation Index System

\begin{tabular}{|c|c|c|c|}
\hline Target Layer & Level-1 Indexes & Level-2 Indexes & $\begin{array}{l}\text { Weight of the Level-2 } \\
\text { indexes relative to the }\end{array}$ \\
\hline \multirow{5}{*}{$\begin{array}{c}\text { Evaluation of } \\
\text { Construction Quality } \\
\text { Management Effect of } \\
\text { PPP Project }\end{array}$} & \multirow{2}{*}{$\begin{array}{l}\text { Economic benefit } \\
\mathrm{X}_{1} 0.249\end{array}$} & $\begin{array}{l}\text { Quality Management } \\
\text { Expenditure } \mathrm{U}_{11} 0.468\end{array}$ & 0.117 \\
\hline & & $\begin{array}{c}\text { Quality Management } \\
\text { Benefit } \mathrm{U}_{12} 0.532\end{array}$ & 0.132 \\
\hline & \multirow{3}{*}{$\begin{array}{l}\text { Quality Management } \\
\text { Satisfaction of Other } \\
\text { Participants } X_{2} 0.254\end{array}$} & $\begin{array}{c}\text { Satisfaction of } \\
\text { Government Quality }\end{array}$ & 0.065 \\
\hline & & $\begin{array}{l}\text { Satisfaction of Owner } \\
\qquad \mathrm{U}_{22} 0.241\end{array}$ & 0.067 \\
\hline & & $\begin{array}{c}\text { Satisfaction of } \\
\text { Supervisor } \mathrm{U}_{23} 0.251\end{array}$ & 0.062 \\
\hline
\end{tabular}




\section{International Journal of Social Science and Economic Research}

ISSN: 2455-8834

Volume:06, Issue:02 "February 2021"

\begin{tabular}{|c|c|c|c|}
\hline & & $\begin{array}{l}\text { Satisfaction of Designer } \\
\mathrm{U}_{24} 0.468\end{array}$ & 0.061 \\
\hline & \multirow{4}{*}{$\begin{array}{c}\text { Quality Management } \\
\text { Method } X_{3} 0.253\end{array}$} & $\begin{array}{l}\text { Quality Plan Preparation } \\
\text { Method } \mathrm{U}_{31} 0.256\end{array}$ & 0.064 \\
\hline & & $\begin{array}{c}\text { Quality Management } \\
\text { Implementation Method }\end{array}$ & 0.065 \\
\hline & & $\begin{array}{l}\text { Quality Management } \\
\text { Inspection Method } U_{33}\end{array}$ & 0.062 \\
\hline & & $\begin{array}{l}\text { Quality Management } \\
\text { Feedback Method U } \mathrm{U}_{34}\end{array}$ & 0.063 \\
\hline & \multirow{4}{*}{$\begin{array}{c}\text { Innovation and } \\
\text { Improvement of Quality } \\
\text { Management Methods } \\
\mathrm{X}_{4} 0.244\end{array}$} & $\begin{array}{c}\text { Innovation of Quality } \\
\text { Plan Preparation Method }\end{array}$ & 0.062 \\
\hline & & $\begin{array}{c}\text { Innovation of Quality } \\
\text { Management }\end{array}$ & 0.062 \\
\hline & & $\begin{array}{c}\text { Innovation of Quality } \\
\text { Management Inspection }\end{array}$ & 0.060 \\
\hline & & $\begin{array}{l}\text { Innovation of Quality } \\
\text { Management Feedback }\end{array}$ & 0.061 \\
\hline
\end{tabular}

Table 3 Evaluation Index Values of PPP Project Construction Quality Management Effect

\begin{tabular}{l|c|c}
\hline \multirow{2}{*}{ Level-1 Indexes } & Level-2 Indexes & $\begin{array}{c}\text { Weight of the Level-2 indexes } \\
\text { value }\end{array}$ \\
\hline \multirow{2}{*}{ Economic benefit $\mathrm{X}_{1}$} & $\begin{array}{c}\text { Quality Management } \\
\text { Expenditure } \mathrm{U}_{11}\end{array}$ & 75.43 \\
\cline { 2 - 3 } & $\begin{array}{c}\text { Quality Management Benefit } \\
\mathrm{U}_{12}\end{array}$ & 78.68 \\
\hline Quality Management & $\begin{array}{c}\text { Satisfaction of Government } \\
\text { Quality Supervision Department } \\
\text { Satisfaction of Other }\end{array}$ & 67.54 \\
\hline
\end{tabular}


International Journal of Social Science and Economic Research

ISSN: 2455-8834

Volume:06, Issue:02 "February 2021"

\begin{tabular}{|c|c|c|}
\hline \multirow[t]{3}{*}{ Participants $X_{2}$} & Satisfaction of Owner $U_{22}$ & 68.59 \\
\hline & Satisfaction of Supervisor $U_{23}$ & 71.29 \\
\hline & Satisfaction of Designer $\mathrm{U}_{24}$ & 72.34 \\
\hline \multirow{4}{*}{$\begin{array}{l}\text { Quality Management Method } \\
\qquad \mathrm{X}_{3}\end{array}$} & $\begin{array}{l}\text { Quality Plan Preparation } \\
\text { Method } \mathrm{U}_{31}\end{array}$ & 73.57 \\
\hline & $\begin{array}{c}\text { Quality Management } \\
\text { Implementation Method } \mathrm{U}_{32}\end{array}$ & 76.39 \\
\hline & $\begin{array}{l}\text { Quality Management Inspection } \\
\text { Method } U_{33}\end{array}$ & 82.19 \\
\hline & $\begin{array}{l}\text { Quality Management Feedback } \\
\text { Method } \mathrm{U}_{34}\end{array}$ & 80.32 \\
\hline \multirow{4}{*}{$\begin{array}{l}\text { Innovation and Improvement of } \\
\text { Quality Management Methods } \\
\qquad \mathrm{X}_{4}\end{array}$} & $\begin{array}{l}\text { Innovation of Quality Plan } \\
\text { Preparation Method } \mathrm{U}_{41}\end{array}$ & 64.32 \\
\hline & $\begin{array}{c}\text { Innovation of Quality } \\
\text { Management Implementation } \\
\text { Methods } \mathrm{U}_{42}\end{array}$ & 61.45 \\
\hline & $\begin{array}{c}\text { Innovation of Quality } \\
\text { Management Inspection } \\
\text { Methods } \mathrm{U}_{43}\end{array}$ & 66.34 \\
\hline & $\begin{array}{c}\text { Innovation of Quality } \\
\text { Management Feedback } \\
\text { Methods } \cup_{44}\end{array}$ & 67.89 \\
\hline
\end{tabular}


International Journal of Social Science and Economic Research

ISSN: 2455-8834

Volume:06, Issue:02 "February 2021"

Table 4 Correlation Function Values of Each Matter-element to be Evaluated on Each Level in PPP Project Construction Quality Management Effect Evaluation

\begin{tabular}{|c|c|c|c|c|c|c|c|c|c|c|c|c|c|c|}
\hline \multirow[t]{2}{*}{$K_{j}\left(x_{i}\right)$} & \multicolumn{2}{|c|}{$\begin{array}{l}\text { Economic } \\
\text { Benefit } \mathrm{X}_{1}\end{array}$} & \multicolumn{4}{|c|}{$\begin{array}{c}\text { Quality Management } \\
\text { Satisfaction of Other } \\
\text { Participants } X_{2}\end{array}$} & \multicolumn{4}{|c|}{$\begin{array}{l}\text { Quality Management } \\
\text { Method X }\end{array}$} & \multicolumn{4}{|c|}{$\begin{array}{l}\text { Innovation and Improvement of } \\
\text { Quality Management Methods X } 4\end{array}$} \\
\hline & $\mathrm{i}=1$ & $\mathrm{i}=2$ & $\mathrm{i}=1$ & $\mathrm{i}=2$ & $\mathrm{i}=3$ & $\mathrm{i}=4$ & $\mathrm{i}=1$ & $\mathrm{i}=2$ & $\mathrm{i}=3$ & $\mathrm{i}=4$ & $\mathrm{i}=1$ & $\mathrm{i}=2$ & $i=3$ & $\mathrm{i}=4$ \\
\hline$j=1$ & -0.69 & -0.73 & -0.59 & -0.61 & -0.64 & -0.65 & -0.67 & -0.70 & -0.78 & -0.75 & -0.55 & -0.52 & -0.58 & -0.60 \\
\hline$j=2$ & -0.59 & -0.64 & -0.46 & -0.48 & -0.52 & -0.54 & -0.56 & -0.61 & -0.7 & -0.67 & -0.41 & -0.36 & -0.44 & -0.46 \\
\hline$j=3$ & -0.39 & -0.47 & -0.19 & -0.21 & -0.28 & -0.31 & -0.34 & -0.41 & -0.5 & -0.51 & -0.11 & -0.04 & -0.16 & -0.20 \\
\hline$j=4$ & 0.23 & 0.07 & 0.30 & 0.38 & 0.44 & 0.38 & 0.32 & 0.18 & -0.11 & -0.02 & 0.14 & 0.04 & 0.23 & 0.33 \\
\hline$j=5$ & -0.16 & -0.06 & -0.28 & -0.27 & -0.23 & -0.22 & -0.20 & -0.13 & 0.14 & 0.02 & -0.31 & -0.32 & -0.29 & -0.27 \\
\hline
\end{tabular}

STEP4: Calculate the correlation degree of each Level index with respect to each level $\mathrm{j}$ and evaluate the level

Using Equation (4) and combining with the index weight values given in Table 2, the economic benefits of PPP project construction quality management, the quality management satisfaction of other participants, the innovation and improvement of quality management methods, and the overall effect are calculated, as shown in Table 5.

Table 5 Evaluation of PPP Project Construction Quality Management Effect

\begin{tabular}{c|c|c|c|c|c|c|c}
\hline$K_{j}(p)$ & Level-1 & Level-2 & Level-3 & Level-4 & Level-5 & Max \\
\hline $\begin{array}{c}\text { Economic } \\
\text { Benefits }\end{array}$ & -0.178 & -0.154 & -0.107 & 0.035 & -0.026 & 0.035 \\
\hline $\begin{array}{c}\text { Quality } \\
\text { management }\end{array}$ & -0.159 & -0.127 & -0.063 & 0.095 & -0.064 & 0.095 \\
\hline $\begin{array}{c}\text { Quality } \\
\text { Management }\end{array}$ & -0.184 & -0.161 & -0.115 & 0.025 & -0.011 & 0.025 \\
\hline $\begin{array}{c}\text { Innovation } \\
\text { and }\end{array}$ & -0.138 & -0.102 & -0.030 & 0.045 & -0.073 & 0.045 \\
\hline $\begin{array}{c}\text { Overall } \\
\text { Effect }\end{array}$ & -0.659 & -0.544 & -0.315 & 0.200 & -0.174 & 4 \\
\hline
\end{tabular}

\subsection{Analysis of evaluation results}

According to the results of PPP project construction quality management effect evaluation, it can be seen that in the process of project implementation, on the whole, the results achieved by the project implementation organization in quality control are at the level of four, i.e. higher level. In 


\section{International Journal of Social Science and Economic Research}

ISSN: $2455-8834$

Volume:06, Issue:02 "February 2021"

addition, the four aspects of the project's quality control, namely, economic benefits, satisfaction of other participants in quality management, quality management methods, innovation and improvement of quality management methods, are also at a higher level.

\section{Countermeasures and Suggestions on Construction Quality Management of PPP Project}

According to the evaluation of PPP project construction quality management results, it is found that the construction quality management of PPP projects is generally at a high level, as well as economic benefits, quality management satisfaction of other participants, quality management methods, innovation and improvement of quality management methods. However, it can be seen that there is still a big gap between the project implementation agencies and the highest level in PPP project construction quality management, and these gaps are reflected in economic benefits, quality management satisfaction of other participants, quality management methods, innovation and improvement of quality management methods, etc. This requires the project implementing agencies to strengthen further management in view of the above aspects, so as to continuously adapt to the requirements of changes and development in the new situation and adopt various ways to improve the effectiveness of project construction quality management.

Specifically, the quality management improvement strategy suggestions for PPP project implementing agencies mainly include the following two aspects:

(1) In view of the problems existing in the quality management satisfaction of other participants, PPP project implementing agencies should strengthen various communication work. Communication is not only limited to the PPP project implementation organization and other participants, but also needs communication within the PPP project implementation organization itself. Based on this, on the one hand, PPP project implementation agencies should be able to ensure the full cooperation of internal personnel through the implementation of a series of communication systems, communication rules and communication documents; On the other hand, a regular meeting system and a document transmission system are established. At the same time, with the help of the information platform, hardware sharing is carried out with other participants, thus effectively ensuring the timeliness of information transmission in the information construction process and ensuring the smooth implementation and development of the information construction. In addition, while conducting formal exchanges, the feelings of all participants are communicated through informal meetings, dinners and other means to ensure the smooth development of the project.

(2) Aiming at the problems existing in the innovation and improvement of quality management methods, PPP project implementing agencies should strengthen internal staff training, reeducation and other aspects of the work to make employees understand the current more 


\section{International Journal of Social Science and Economic Research}

ISSN: $2455-8834$

Volume:06, Issue:02 "February 2021"

advanced quality management methods, quality management tools, etc., so as to help each employee to establish a strong knowledge reserve, and then guide the specific development of the work in the process of work development. As a result, the continuous innovation and improvement of the project construction quality management methods is ensured.

(3) In view of the problems existing in the economic benefits of quality management, PPP project implementing agencies should strengthen risk management. As there are more uncertainties in the implementation of the project, the project implementers are required to establish a perfect project risk early warning mechanism. In the process of PPP project implementation, a risk early warning mechanism should be established. Through the construction of an early warning mechanism for the important risk factors that may exist in the process of PPP project implementation, the early warning mechanism can respond in advance, which ensures the smooth implementation of PPP projects. In order to ensure the effective development of project risk management, PPP project implementation agencies should also establish complete risk emergency plans. When analyzing the possible hazards of each major risk event and risk factor, they should establish their own risk emergency plans, so as to be able to take prompt countermeasures when risk events occur, reduce the impact degree of risks and ensure the smooth implementation of the project.

\section{Acknowledgements}

This work is supported by the National Natural ScienceFoundation of China (\# Project No. 71801130), Jiangsu Social Science Foundation Project (\# Project 18GLD013).

\section{References}

[1]. Bo Liu, Ju-qin Shen, Zhao-jian Meng, Fu-hua Sun. A Survey on the Establishment and Application of Social Capital Partner Selection System for the New Profit PPP Project. KSCE Journal of Civil Engineering10 (2018): 3726-3737. Print.

[2]. Eurasia PPP Network, translated by Wang Shouqing. Case Analysis of Public-Private Partnership (PPP) in Eurasia Infrastructure Construction. Shenyang: Liaoning Science and Technology Press2010: 11-15. Print.

[3]. Hu Li. Research on risk control of urban infrastructure financing by PPP model.Chongqing: Chongqing University Press2013: 26-27. Print.

[4]. Wu YN, Li LWY, Xu RH, Chen KF, Hu Y, Lin XS. Risk assessment in straw-based power generation public-private partnership projects in China: A fuzzy synthetic evaluation analysis. Journal of Cleaner Production 161 (2017): 977-990. Print. 
[5]. Xiong W, Zhao XB, Yuan JF, Luo S. Ex Post Risk Management in Public-Private Partnership Infrastructure Projects. Project Management Journal 48.3 (2017): 76-89. Print.

[6]. Li Y, Wang, XY, Wang YH. Using Bargaining Game Theory for Risk Allocation of PublicPrivate Partnership Projects: Insights from Different Alternating Offer Sequences of Participants. Journal of Construction and Management 143.3 (2017). Print.

[7]. Rivera NR. Public-Private Partnerships in Disaster Risk Reduction: The Case of the Chemical Industry of Coatzacoalcos, Mexico. Gestion Y Politica Publica 26.1 (2017): 105-138. Print.

[8]. Carpintero, S and Petersen, OH. Public-private partnerships (PPPs) in local services: risksharing and private delivery of water services in Spain. Local Government Studies 42.6(2016): 958-979. Print. 